\title{
THE AMAZON DENSE GNSS METEOROLOGICAL NETWORK A New Approach for Examining Water Vapor and Deep Convection Interactions in the Tropics
}

\author{
by David K. Adams, Rui M. S. Fernandes, Kirk L. Holub, Seth I. Gutman, \\ Henrique M. J. Barbosa, luiz A. T. Machado, Alan J. P. Calmeiros, Richard A. Bennett, \\ E. Robert Kursinski, luiz F. Sapucci, Charles DeMets, Glayson F. B. Chagas, Ave Arellano, \\ Naziano Filizola, Alciélio A. Amorim Rocha, Rosimeire Araújo Silva, lilia M. F. Assunção, \\ Glauber G. Cirino, theotonio Pauliquevis, Bruno T. T. Portela, André Sá, Jeanne M. de Sousa, \\ AND LUDMILA M. S. TANAKA
}

The Amazon Dense GNSS Meteorological Network provides high spatiotemporal resolution, all-weather precipitable water vapor for studying the evolution of continental tropical and sea-breeze convective regimes of Amazonia.

T he meteorology and climate of the equatorial tropics are dominated by atmospheric convection, which presents a rather challenging range of spatial and temporal scales to capture with presentday observational platforms (Mapes and Neale 2011; Moncrieff et al. 2012; Zhang et al. 2013). Over a period of a few hours, shallow convection (of order 1-10 km in horizontal scale) can transition to deep precipitating convection (of order $10-100 \mathrm{~km}$ ) and then organize into mesoscale convective systems (of order $100-1000 \mathrm{~km}$ ) with lifetimes ranging from several hours to greater than 1 day. Furthermore, complex feedbacks exist between atmospheric convection and the thermodynamic environment, particularly water vapor fields, in which convection develops [see Sherwood et al. (2009) for a review of convection and water vapor interactions].

Understanding and modeling tropical convection have been hampered by the dearth of long-term observations resolving the mesoscale. For example, large-scale models where convection is parameterized have poorly represented the diurnal cycle of convective precipitation, particularly over land, possibly resulting in the degradation of model clouds, radiation fields, and large-scale dynamics (Betts and Jakob 2002a,b; Bechtold et al. 2004). While singlecolumn and high-resolution models (cloud resolving to large-eddy simulations) are useful tools (Betts and Jakob 2002b; Grabowski and Moncrieff 2004; Grabowski et al. 2006), they are not a substitute for observations. Many efforts have focused on what controls the shallow-to-deep convection transition, a process often missing in coarse models with separate shallow and deep convection schemes (Betts and Jakob 2002a,b; Grabowski et al. 2006; Kuang and Bretherton 2006; Khairoutdinov and Randall 2006; Waite and Khouider 2010; Wu et al. 2009; Hohenegger and Stevens 2013). Mechanisms to explain the 
shallow-to-deep transition include cold pool formation (Kuang and Bretherton 2006; Khairoutdinov and Randall 2006; Schlemmer and Hohenegger 2014), cumulus congestus moistening of the free troposphere (Waite and Khouider 2010), increasing cloud buoyancy (Wu et al. 2009), and dynamically forced, large-scale vertical motions and attendant water vapor convergence (Hohenegger and Stevens 2013). Whatever the mix of these model-elucidated physical mechanisms, even high-resolution models must somehow be evaluated with real-world observations, which, unfortunately, are sorely lacking in the tropics at the necessary spatial-temporal scale.

Geostationary satellites are the backbone of observational studies of the evolution and life cycle of tropical convection (Sherwood and Warhlich 1999; Masunaga 2013). Visible and IR cloud imagery can document the evolution of cumulus fields at high spatial resolution and adequate temporal resolution (15-30 min). However, water vapor is more challenging to measure from space. Infrared radiometers for measuring column water vapor are limited to clearsky conditions, while microwave observations, although all weather, are unreliable over land and sporadic over water. Long-term, surface-based, mesoscale meteorological networks thus have a unique role to play. Unfortunately, only brief field campaigns in the continental tropics, such as the Amazon, have been carried out as a result of logistical difficulties [e.g., Atmospheric Boundary Layer Experiment (ABLE) 2B (Garstang et al. 1990); Tropical Rainfall Measuring Mission/Large-Scale Biosphere-Atmosphere
Experiment in Amazonia (TRMM/LBA; Silva-Dias et al. 2002; Betts et al. 2009); and currently the Green Ocean Amazon experiment (GOAmazon)]. Global Navigational Satellite System (GNSS) meteorology [the global positioning system (GPS) being the most commonly used] can help in this regard.

For two decades, GNSS/GPS meteorology has offered relatively inexpensive, high-frequency ( $\sim 5 \mathrm{~min})$, all-weather, "precipitable" or column-integrated water vapor (PWV) values within 1-2-mm accuracy compared to radiosondes and radiometers (Bevis et al. 1992; Rocken et al. 1993; Duan et al. 1996; Wolfe and Gutman 2000; Sapucci et al. 2007). A related spacebased technique, GPS radio occultation, provides water vapor profiles but is too infrequent to capture water vapor field evolution at a given location (Kursinski et al. 2000). Estimation of the effects of cloud liquid/ ice water, precipitation, and atmospheric aerosols/ dust on GNSS signals can be found in Solheim et al. (1999). For process-oriented, mesoscale studies of water vapor-convection interactions, a network of sites is needed. The GNSS cone of observation has an approximately $10-\mathrm{km}$ radius, covering the spatial and temporal scales at which the shallow-to-deep transition occurs and upscale convective organization begins (Moncrieff et al. 2012). With GNSS meteorology arranged in a network, mesoscale convective organization and associated water vapor fields can be documented. Surprisingly, after two decades, most GNSS studies have focused on the technique itself, validating radiosondes, radiometers, or satellite platforms, or as ancillary data for large-scale studies
AfFiliations: Adams-Centro de Ciencias de la Atmósfera, Universidad Nacional Autónoma de México, México City, México; FERNANDES - Instituto Dom Luíz, Universidade da Beira Interior, Covilhã, Portugal, and Faculty of Aerospace Engineering, Delft University of Technology, Delft, Netherlands; Holub AND GUTMANOffice of Oceanic and Atmospheric Research, National Oceanic and Atmospheric Administration, Boulder, Colorado; BARBOSAInstituto de Física, Universidade de São Paulo, São Paulo, Brazil; Machado, Calheiros, and Sapucci一Centro de Previsão de Tempo e Estudos Climáticos, Instituto Nacional de Pesquisas Espaciais, São Paulo, Brazil; BenNetT-Department of Geosciences, The University of Arizona, Tucson, Arizona; KURSINSKI*_Moog Advanced Missions and Science, Golden, Colorado; DeMets-Department of Geoscience, University of Wisconsin-Madison, Madison, Wisconsin; Chagas, Rocha, Silva, Assunção, Cirino, Portela, Tanaka, and DE SousA-Programa de Pós Graduação em Clima e Ambiente, Universidade do Estado do Amazonas, Manaus, Amazonas, Brazil; Arellano-Department of Atmospheric Sciences, The University of Arizona, Tucson, Arizona; FILIzolA-Departamento de Geografia, Universidade Federal do Amazonas, Manaus, Amazonas,
Brazil; Theotonio Pauliquevis-Departamento de Ciências Exatas e da Terra, Universidade Federal de São Paulo, Diadema, Brazil; SÁDepartamento de Engenharia e Tecnologia, Instituto Politécnico da Guarda, Guarda, Portugal, and Departamento de Informática, Universidade da Beira Interior, Covilhã, Portugal.

* CURRENT AFFILIATION: Space Sciences and Engineering,

Boulder, Colorado

CORRESPONDING AUTHOR: David K. Adams, Centro de Ciencias de la Atmósfera, Universidad Nacional Autónoma de México, Circuito Exterior s/n, Ciudad Universitaria, Del. Coyoacán 04510 , México D.F.

E-mail: dave.k.adams@gmail.com

The abstract for this article can be found in this issue, following the table of contents.

DOI:I0.II75/BAMS-D-I3-00I7I.I

A supplement to this article is available online (I0.II75/BAMS-D-I3-00I7I.2)

In final form 13 January 2015

(C2015 American Meteorological Society 
or numerical weather data assimilation and/or prediction. Mesoscale, process-oriented GNSS studies are few, and even less so for the deep tropics.

The Amazon Dense GNSS Meteorological Network (ADGMN) was created to address these issues of water vapor-convection interactions. In this brief overview of the ADGMN, we encapsulate the motivations and goals (section 3 ) as well as the experimental design (section 4) for both the Belem and Manaus networks. An example of the diurnal cycle of sea-breeze convection for Belem along with ideas for future work for this network is presented in section 5 . Results from the Manaus network (section 6) also describe the diurnal cycle with respect to topographic effects and the seasonal evolution, given that the dataset spans 1 year. Prospects for expanding large-scale GNSS networks in the tropics, specifically in the Caribbean and Mexico, are then surveyed. A secondary goal is to demonstrate that GNSS meteorology is viable even in regions fraught with logistical difficulties such as the Amazon.

THE ADGMN: MOTIVATIONS AND AIMS. Dense GNSS meteorological networks are not new in Europe (Champollion et al. 2005; Bastin et al. 2007; Brenot et al. 2013), Japan (Seko et al. 2004), or the United States (Champollion et al. 2009) and neither are GNSS studies of deep convection (Mazany et al. 2002; Kursinski et al. 2008; Brenot et al. 2013). However, the deep tropics offer new challenges as well as unique weather situations to explore. Establishing any type of meteorological network in the Amazon is a challenging logistical task as suitable sites are few and far between. Fortunately, the GNSS site infrastructure for deriving GNSS PWV is not nearly as demanding as for geodetic or plate tectonics studies. Highly nonideal platforms such as flux towers (Adams et al. 2011a) or even moving oceanic vessels (Rocken et al. 2005; Kealy et al. 2012) can be utilized (see the sidebar on GNSS meteorology at unconventional locations).

The overarching motivation for the creation of the ADGMN was to address convection-humidity interactions, a major scientific challenge (Derbyshire et al. 2004; Kuang and Bretherton 2006; Waite and Khouider 2010; Hohenegger and Stevens 2013). Convective parameterizations are too insensitive to tropospheric humidity because of inadequate representation of the entrainment of environmental air into convective updrafts (Kuang and Bretherton 2006; Del Genio 2012). Entrainment in clouds remains a vital research question (Romps and Kuang 2010; Yeo and Romps 2013; Sherwood et al. 2013) and is a leading source of climate model uncertainty
(Rougier et al. 2009). Furthermore, upscale growth and convective organization, also poorly represented with parameterized convection, are strongly linked to convective downdrafts/cold pools, which, in turn, are sensitive to the vertical humidity structure (Tompkins 2001a,b). A few convective parameterizations are beginning to address these effects (Rio et al. 2009; Mapes et al. 2009; Park 2014). Although neither entrainment nor the vertical humidity structure can be directly captured with GNSS dense meteorological networks (however, see section 6a), they can provide target relationships modified parameterization schemes must be able to replicate.

Diagnostic studies are needed to turn raw data into such model target results and suggest which physical processes are dominant (e.g., surface latent heat fluxes, horizontal advection, and water vapor convergence in the evolution of water vapor fields at these newly seen spatial and temporal resolutions. Adams et al. (2013) inferred, using GNSS PWV from a single station, a 4 -h water vapor convergence time scale indicative of the shallow-to-deep transition for the equatorial continental tropics. With dense mesoscale networks, cross correlations and other techniques will be able to identify the spatial-temporal scales of variability in PWV fields, putting mechanistic deductions on a firmer basis. Furthermore, PWV, in itself, is actually a much more valuable quantity than its integral nature might suggest (Holloway and Neelin 2009; Lintner et al. 2011). Empirical PWV-precipitation relationships are surprisingly strong (Zeng 1999; Bretherton et al. 2004) and theoretical views of tropical convection such as "self-organized criticality" (Neelin et al. 2009; Peters et al. 2009) or that of largescale "thermodynamic control" (Raymond 2000) depend critically on PWV. These types of studies, all over oceanic regions, could be greatly expanded with GNSS meteorology, and data over land may provide unique tests of such theories.

\section{EXPERIMENTAL DESIGN, INSTRUMEN-} TATION, AND DATA. The ADGMN campaign consisted of two experiments: a 6-week campaign in and around Belem, which coincided with the Cloud Processes of the Main Precipitation Systems in Brazil: A Contribution to Cloud-Resolving Modeling and to the Global Precipitation Measurement (CHUVA) Belem campaign (Machado et al. 2014), and a 1-yr campaign in and around Manaus. As originally proposed (Adams et al. 2011b), the ADGMN project was intended to coincide in Manaus with the CHUVA campaign in 2012. However, with the confirmation of the U.S. Department of Energy's Green 


\section{GNSS METEOROLOGY IN LOGISTICALLY DIFFICULT SITES}

s noted, the spread of GNSS

A meteorology into logistically difficult regions such as the Amazon requires compromises when it comes to GNSS installations. Geodetic requirements for antenna permanence, such as rigid monumentation, full-sky visibility, and absence of obstructions can be relaxed for GNSS meteorological applications without serious deterioration of the data collected. Even in the extreme case of installing a GNSS antenna on scaffolding above the forest canopy, useful data can still be collected if the motions of the scaffold were constrained to minimize vertical displacements of the antenna phase center over time. Relaxing these requirements also reduces the financial burden on the campaign, since local/indigenous resources can be exploited to accomplish the experimental objectives. For the Amazon dense network campaign sites, perfectly valid PWV values were captured from a 55-m Instituto Nacional de Pesquisas da Amazônia (INPA) LBA flux tower (ZF29); a chicken coop (HORT); housing on stilts (palafitas), which suffered annual flooding (CTLO); and residential housing (BJRN). (See Fig. SBI for locations.) For permanent sites that serve both the geodesy/ geophysics and the meteorology community, more stringent conditions exist and, clearly, these sites would not be adequate for measuring the necessary millimeter displacements in position.

For meteorological campaigns (longer than several weeks), the lack of a need for stable monumentation drastically lowers installation costs. A geodetic grade receiver-antenna and a surface meteorological station (with real-time capacity where the Internet is available) now cost less than $\$ 10,000$ (U.S. dollars) for a meteorological-campaign-ready installation. These receivers-antennas are extremely robust and durable and serve as a datalogger with greater than I-yr capacity for data storage at the typical data collection rate required. Energy requirements are small $(\sim 4 \mathrm{~W})$ so solar panels and deep-cycle batteries can be employed, although maintenance costs for deep-cycle batteries depend on the climatic regime. Given the frequent power outages in the Amazon and a lack of solar panels for the ADGMN (at both Belem and Manaus), a workable energy setup consisted of a trickle charger plugged into local current and two car batteries in parallel giving at least 2 days worth of independent power.

The entire process of installation, maintenance, and data collection is relatively straightforward. Students from the Clima e Ambiente graduate program at the Universidade do Estado do Amazonas in Manaus participated in the installation of both the Belem and Manaus networks as well as the maintenance and data collection from these sites.
Ocean Amazon (GOAmazon) campaign (see http:// campaign.arm.gov/goamazon2014/), an elaborate experiment for examining atmospheric chemistry, aerosols, cloud microphysics, and convective precipitation in a tropical continental setting, CHUVA Manaus was postponed until 2014 when more instrumentation was deployed. Nevertheless, constructing one phase of the ADGMN in Belem was fortuitous in that it was a successful demonstration of a dense GNSS meteorological network in a distinctive tropical convective regime driven by the sea breeze.

The Belem dense network. Convective development in the tropical sea-breeze regime has been studied in theoretical modeling work and observationally in a wide variety of locales around the globe (Moncrieff and Liu 1999; Carbone et al. 2000; Mapes et al. 2003; Fovell 2005; Robinson et al. 2013). The sea breeze, driven by differential land-sea heating, orchestrates the timing and location of convective cell initiation (Moncrieff and Liu 1999; Fovell 2005; Robinson et al. 2013). However, once the convective cells begin to precipitate, cold pools/gust fronts and the environmental thermodynamical and shear conditions then determine whether upscale growth into propagating squall lines or mesoscale convective systems occur (Moncrieff and Liu 1999; Carbone et al. 2000). The Belem coastal region, unlike many previous tropical sea-breeze studies, such as Florida (Ulanski and Garstang 1978), is the coast of an enormous continental region. The Belem area has two particularities: the striking punctuality ${ }^{1}$ of the late afternoon convective activity (Kousky 1980; Angelis et al. 2004) and its role as the initiation point of spectacular, long-lived squall lines up to $2000 \mathrm{~km}$ in length penetrating, and even crossing, the Amazon basin (Greco et al. 1990; Garstang et al. 1994; Cohen et al. 1995; Alcântara et al. 2011).

The Belem Dense GNSS Meteorological Network was initiated on 25 May and dismantled on 7 July 2011. The network was composed of 15 GNSS/meteorological stations that provided high-frequency (5 min) PWV data as well as surface meteorological variables (Fig. 1). Two nearly perpendicular transects were constructed: 1) southeast-northwest along the dominant lower- to midtropospheric eastsoutheasterly winds (BSMG-BSPC-BMSQ-BSOR $\sim 150 \mathrm{~km}$ ) and 2) southwest-northeast, essentially perpendicular to the Atlantic coastline (BABT-BSSG $\sim 100 \mathrm{~km})$. A cluster of stations, centered in Belem

\footnotetext{
${ }^{1}$ A common expression in Belem is "A gente se encontra antes ou depois da chuva?" (Should we meet before or after the rain?).
} 

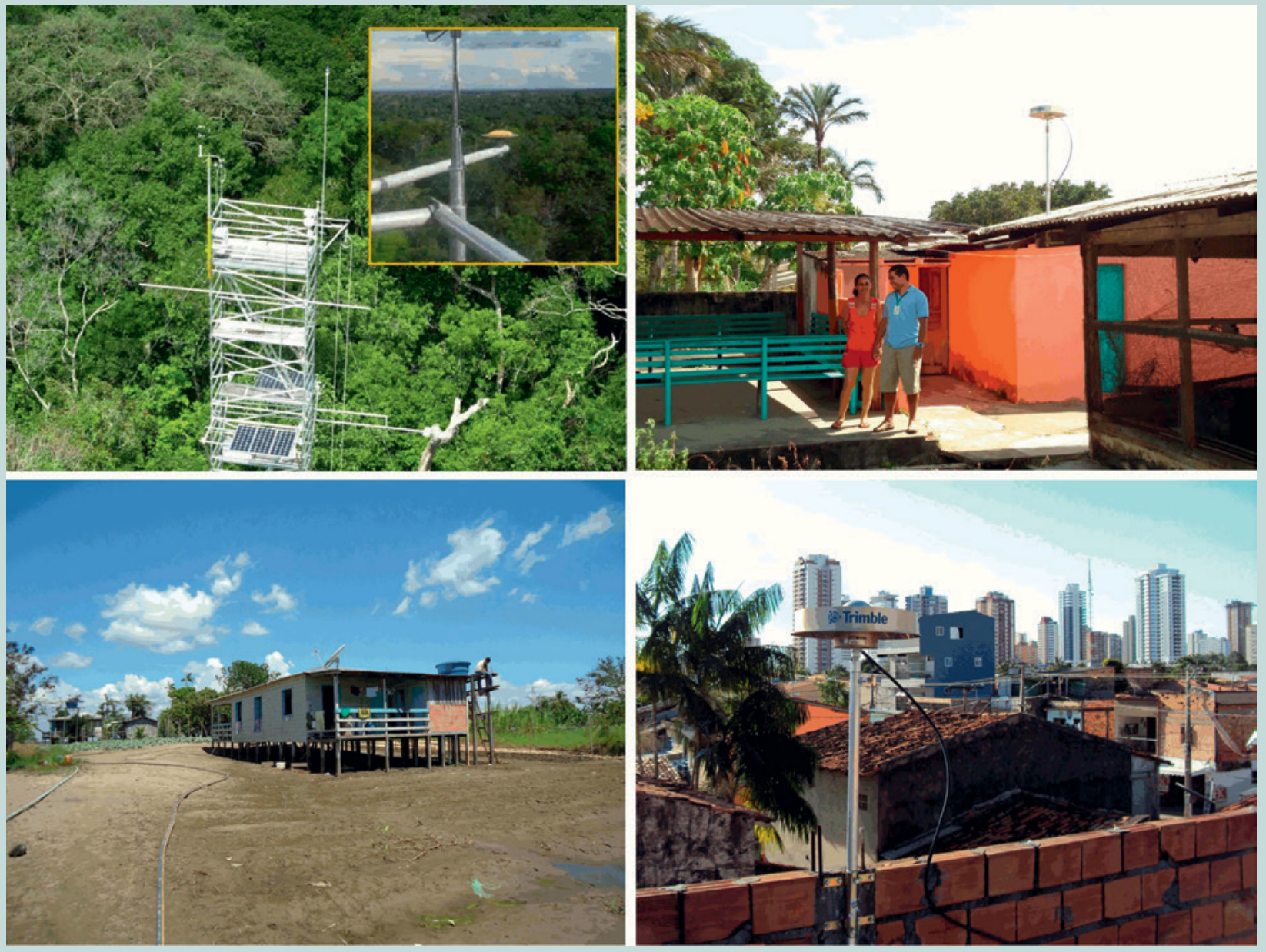

FIG. SBI. Photos of ADGMN sites: (top left) Manaus station (ZF29), (top right) Manaus station (HORT), (bottom left) Manaus station (CTLO), and (bottom right) Belem station (BJRN).

with approximately $10-\mathrm{km}$ separation distance were collocated with the CHUVA instrumentation array, which is described next.

The CHUVA project consisted of six field campaigns in different convective regimes in Brazil, including the sea-breeze regime of Belem and the continental tropical rain forest regime of Manaus. CHUVA was motivated by the need to better observe cloud microphysics in both warm and cold clouds and their associated precipitation processes in the tropics (Calheiros and Machado 2014). The CHUVA Belem campaign included a suite of instrumentation for documenting environmental thermodynamic conditions and cloud evolution and microphysics. Three radiosonde sites supplied thermodynamic stability variables, water vapor data, and wind profiles. A microwave radiometer furnished high-frequency vertical water vapor structure and cloud liquid water profiles. An X-band dual-polarization radar (X-Pol) was utilized to capture the development of convective clouds. Surface meteorological stations and disdrometers characterized the rainfall intensity and hydrometeors, respectively. Twice-daily (0800 and 2000 LT) radiosondes were launched (Val de Cans International Airport in Belem, near station BEMA, SBBE 82193) through the duration of the experiment. In addition, a 7-day intensive observational period included four extra launches per day $(0000,0600$, 1200 , and 1800 UTC) in a triangular arrangement with approximately $120-\mathrm{km}$ separation distance between SBBE, São Miguel (BSMG), and farther to the south at Tomé Açu $\left(2.4167^{\circ} \mathrm{S}, 48.1500^{\circ} \mathrm{W}\right.$; not seen in Fig. 1). Details can be found in Machado et al. (2014) and online (http://chuvaproject.cptec.inpe.br). 


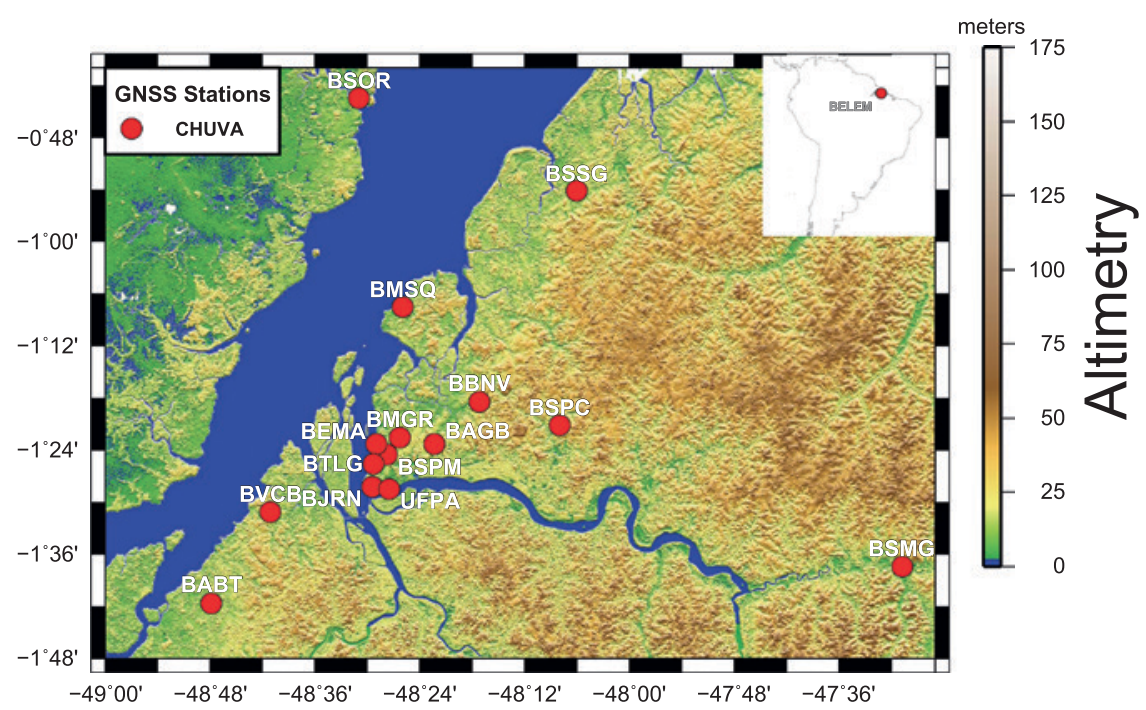

FIG. I. Map of the Belem Dense GNSS Meteorological Network during the CHUVA experiment (Jun 20II). Sounding sites were BSMG and BSSE (near $B E M A)$. Tomé $A c ̧ u$ is to the south of the mapped region. The large water body west of Belem is the Bahia de Marajó. additional surface meteorological equipment. The station distribution can be categorized as low-lying river sites (CMP1, CHR5, CTLO, EMIR, HORT, MNCP, MNQI, PDAQ, and TMB7), interior stations (CDN2, CDN4, GOAM, INPA, IRAN, JPL6, NAUS, and PNT8), and foresttransition stations (EMBP, RDCK, RPDE, and TRM3). Site ZF29 (blue, northernmost site); a rain forest GNSS site was rather unconventional, being located atop a 55-m flux tower (K34) (see Fig. SB1 in the sidebar on GNSS meteorology) of the LBA, thereby offering an unprec-

The Manaus Dense GNSS Meteorological Network. The area around Manaus $\left(2.61^{\circ} \mathrm{S}, 60.21^{\circ} \mathrm{W}\right.$; see Fig. 2), in the central Amazon, in many respects is the quintessential continental tropical regime. Rainfall totals are large $\left(\sim 2,500 \mathrm{~mm} \mathrm{yr}^{-1}\right)$ and distributed throughout the year, but with a notable dry season from July to September and with the most frequent precipitation from January to April (Machado et al. 2004). Topographic variation across the network, from Amazon River stations to forest stations, is greater than for Belem but small nonetheless $(\sim 150 \mathrm{~m})$. It has been noted that these weak topographic gradients can induce local circulations with impacts on the precipitation distribution (Fitzjarrald et al. 2008; Betts et al. 2009). Typical of continental tropical regimes, there is a strong afternoon peak in convective rainfall; however, nocturnal events are not infrequent and traveling squall lines can arrive in or out of phase with diurnal surface heating (Greco et al. 1990; Angelis et al. 2004; Adams et al. 2013).

The Manaus network commenced in April 2011 with 12 GNSS meteorological stations. With the termination of the Belem campaign, the Manaus network expanded to 22 stations for the last 9 months (August 2011-April 2012). Although the profiling instrumentation of CHUVA was not available, twice-daily radiosondes were launched from SBMN (see Fig. 2). In addition, the station at Embrapa (EMBP; green; north of Manaus) included a UV Raman lidar (beginning September 2011) for frequent ( $5 \mathrm{~min}$ ) nighttime water vapor profiles, as well as disdrometer and edented look at rain forest PWV (Adams et al. 2011a). Although the network's primary goal was to study the mesoscale evolution of convection, indirect measures of local circulations (e.g., between the Amazon River and surrounding forest) and their intensity can also be gauged. Furthermore, the network's 1-yr duration means that the dry, wet, and transition seasons were observed and seasonal effects on convective organization and PWV fields are available for analysis.

\section{BELEM RESULTS: THE DIURNAL CYCLE OF SEA-BREEZE CONVECTION. For the} 6-week duration of the Belem experiment, days were categorized as "convective" (22 days) or "nonconvective" (19 days) based solely on a minimum cloud-top temperature of $240 \mathrm{~K}$ or below over the central portion of the network and a report of precipitation at at least one site during the afternoon or evening. Composites of the temporal evolution of PWV and cloud-top temperature are shown in Fig. 3. To gauge the environmental conditions in which convection developed (or not), average thermodynamic stability (CAPE and CIN), water vapor profiles, and wind shear magnitude were calculated. The Belem network lacks any significant variations in topography along the coast and the bay, and boundary layer thermodynamics are also quite uniform. During the intensive observational period, the standard deviations of mixing ratio and temperature averaged over the lowest $50 \mathrm{hPa}$ in all soundings from all three sites and all launch times were $1.1 \mathrm{~g} \mathrm{~kg}^{-1}$ and $1.0^{\circ} \mathrm{C}$, respectively. The reasons for convective 
development on any given day are quite subtle.

The composites of GNSS PWV and cloud-top temperature for three stations (BSSG, BBNV, and BABT), aligned southwest-northeast, almost perpendicular to the broadscale coastline and advancing sea-breeze lines, are shown in Fig. 3. Morning values of PWV and cloud-top temperature are similar for convective and nonconvective days, but differences begin to appear about 1000 LT. The value of $\Delta \mathrm{PWV} / \Delta t$, which is mostly a measure of water vapor convergence (Adams et al. 2013), was estimated between the upward- and downwardpointing triangles for each site in Fig. 3. The propagation speed of the convective perturbation between BSSG-BBNV and BBNV-BABT was calculated by dividing the between-station distance by the time difference between the maximum PWV readings at each site (upward-pointing triangles). These two propagation speeds were then averaged. We find that $\Delta \mathrm{PWV} / \Delta t$ is more than $50 \%$ greater for convective days, and the convective propagation speed is nearly twice as large (see Table 1).

What promotes or inhibits the development and propagation of convection in Belem's sea-breeze regime? In addition to propagation speed and water vapor convergence, environmental conditions, including moist stability as measured by CAPE/CIN, the wind shear magnitude between the steering level and near-surface layer (Carbone et al. 2000), and water vapor, both near the surface and from 850 to $500 \mathrm{hPa}$, were calculated from the $0800 \mathrm{LT}$ soundings (Table 1). The vertical water vapor distribution and wind shear magnitude (and direction; not shown) are essentially the same for both convective and nonconvective days. However, morning CAPE is twice as large on convective days. Nevertheless, $1 \mathrm{~g} \mathrm{~kg}^{-1}$ and $1^{\circ} \mathrm{C}$ increases in surface mixing ratio and temperature (i.e., the observed standard deviations) would increase CAPE by more than $1,000 \mathrm{~J} \mathrm{~kg}^{-1}$, which is larger than the convective-nonconvective difference of $500 \mathrm{~J} \mathrm{~kg}^{-1}$. Although the number of cases is small, it would be difficult to argue that deep convection or its suppression

are solely functions of environmental instability, wind shear, and water vapor structure.

Convective growth or suppression appears to be closely tied to the morning formation of convective lines within $30 \mathrm{~km}$ or so of the coast (presumably along the sea-breeze front). Time loops of Geostationary Operational Environmental Satellite-12 (GOES-12) IR imagery over a much larger region than the Belem network support this contention. Figure 3 shows the average cloud-top temperature at $1230 \mathrm{LT}$ for convective and nonconvective days. Convective days begin with the formation, by $1000 \mathrm{LT}$, of nearcoastal cumulus cells. By noon, cumulus congestus develops above the freezing level, begins to coalesce, and commences its propagation inland. In contrast, for nonconvective days, cumulus cells develop later in the morning, remain closer to the coast, and only weakly coalesce, quickly dissipating before propagating farther inland (supplemental material related to this article is available online). These impressions suggest a prominent role for gust fronts and cold pools and secondary development in the organization and propagation of these convective lines. What promotes the initial convective formation along the coast in the first place? Subtle changes in interactions between the sea-breeze front and synoptic-scale flow patterns may be at play, similar to seasonal variability in large-scale flow over the region (Kousky 1980). 


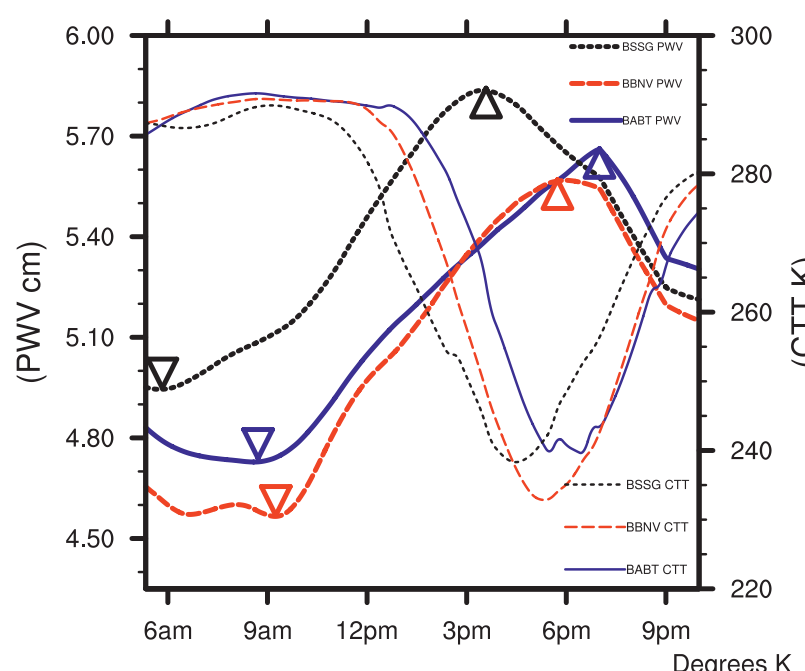

Degrees $\mathrm{K}$

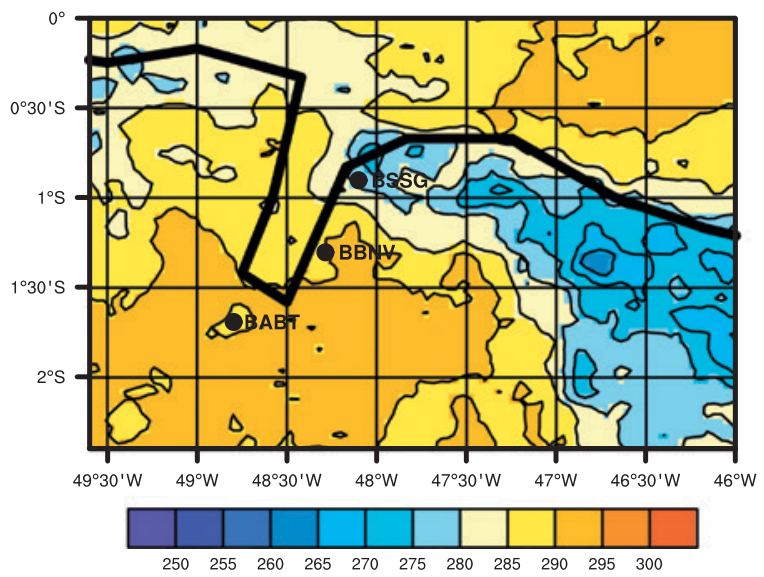

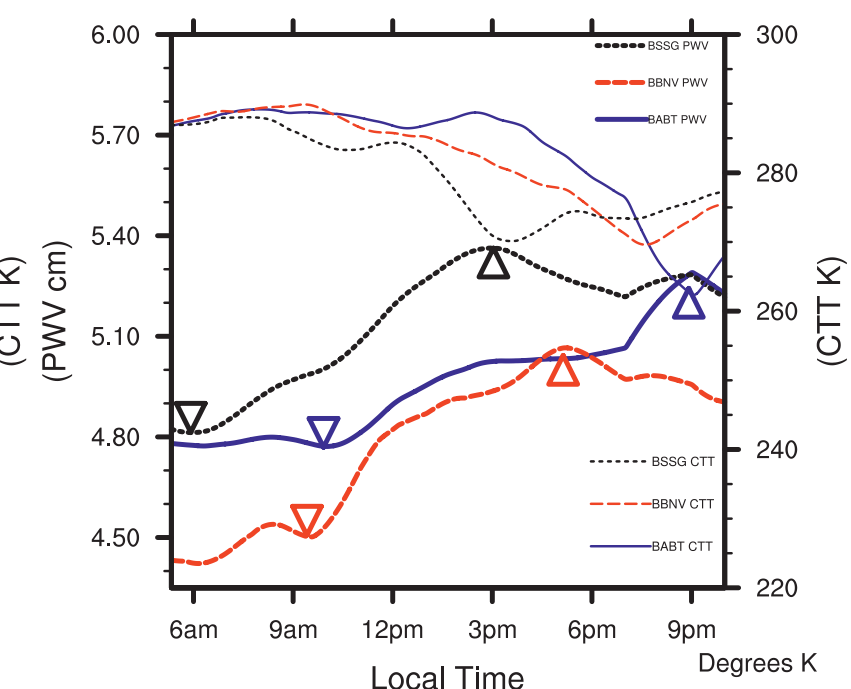

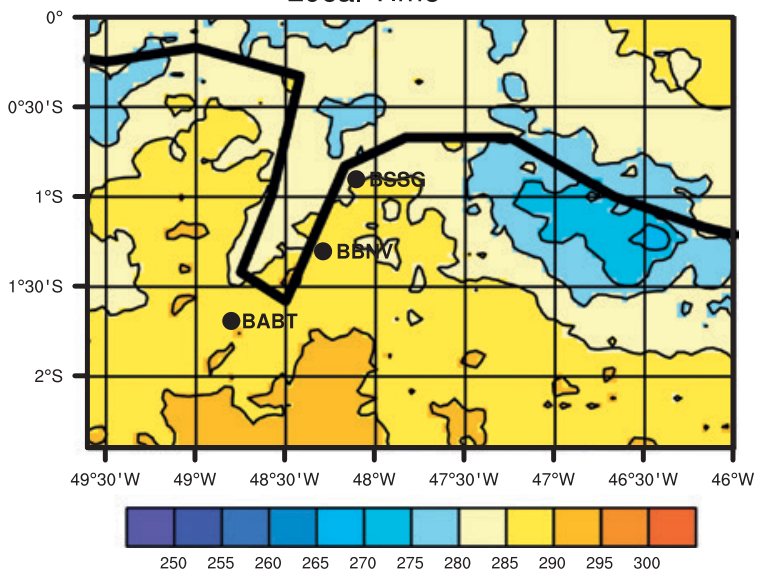

FIG. 3. Plot of time series of average PWV (every $5 \mathrm{~min}$ ) BSSG (black, short dash), BBNV (red, long dash), and BABT (blue, solid), as well as average cloud-top temperature (CTT; every $15 \mathrm{~min}$ ) (identical patterns and colors, but with thin lines) for (top left) convective days $(N=22)$ and (top right) nonconvective days $(N=19)$. Triangles represent the times for which propagation speed and water vapor convergence values were calculated (see Table I and text). (bottom) CTT [ranging from 245 (blue) to $305 \mathrm{~K}$ (red)] at I230 LT for (bottom left) convective and (bottom right) nonconvective days.

Future Belem network studies. Given the soundings, surface meteorological and cloud microphysical data gathered by CHUVA, and the ADGMN, the role of advancing cold pools/gust fronts forcing convection can be surmised in future work. Our portrait of the evolution of Belem sea-breeze convection presented in the previous section, although a bit speculative, is entirely consistent with a quiescent, large-scale, but mildly thermodynamically unstable, environment where premoistening of the free troposphere to support deep convection is not required. Here, propagating cold pools provide the necessary kick for releasing convective instability, leading to cloud growth and precipitation and further propagation. With the existing dense network and CHUVA dataset, dynamic lifting provided by cold pools/ gust fronts can be examined directly through cloud spatial-emporal evolution (X-Pol radar) and visible and IR cloud fields (GOES-12). Surface meteorological stations will provide temperature drops and wind gusts for cold pool/gust front identification and, finally, GNSS stations will furnish $\Delta \mathrm{PWV} / \Delta t$ at each station along the convective line trajectory. Adams et al. (2013) hypothesized, during the transition to deep convection and prior to heavy precipitation, cloud condensate formation and advection and surface evaporation are secondary in the total column water conservation budget. These ideas can be put to the test with the Belem dataset. Furthermore, given the homogeneity in Belem low-level water vapor fields, horizontal advection is weak, and thus GNSS $d(\mathrm{PWV}) / d t$ represents vertical water vapor advection, providing a window into vertical motion, which is very difficult to measure directly. 
MANAUS RESULTS: SEASONAL AND TOPOGRAPHIC EFFECTS ON THE DIUR-

NAL CYCLE. In light of the longer-term deployment of stations in and around Manaus, studies involving the seasonal influences on convection and topographically forced mesoscale circulation can also be addressed. Local topography and vegetated surfaces, perturbed and unperturbed, can induce mesoscale circulation patterns along the Amazon River, which influence cloud and precipitation distributions (Silva-Dias et al. 2004; Fitzjarrald et al. 2008). Local circulations driven by anthropogenic deforestation have, in particular, received attention (Wang et al. 2009; Saad et al. 2010). Local mesoscale breezes can enhance cloud formation over vegetated zones, while suppressing it over the river because of subsidence. Enhanced cloud formation should be associated with increases in precipitation for typical diurnal cycle convection, all else being equal. Fitzjarrald et al. (2008) found that near-river sites do receive less afternoon rainfall as expected, but their nocturnal rainfall can be enhanced as a result of interactions with squall lines and local river geometry.

From the year's worth of Manaus network data, Fig. 4 presents the PWV diurnal cycle as a function of location and season. The diurnal cycle of PWV was calculated at sites representing the interior, the forest, and two river locations for the dry, dryto-wet transition, and wet season, the results of which can be seen in Fig. 4. Based solely on the forest-river contrast, which is difficult to separate from the topographical effect, it is apparent that the forested site (ZF29) experiences a more robust diurnal cycle, particularly when compared with a river site (CHR5). The seasonal effect on the PWV diurnal cycle is principally that water vapor convergence is earlier in the day (true for all sites) and generally less intense during the wet season. The dry season and dry-to-wet transition seasons have larger-amplitude diurnal rises for both the interior site (JPL6) and ZF29. This is not true, however, for CHR5 where the dry season diurnal cycle is strongly muted. The behavior of all of the river sites is not consistent and appears to be strongly influenced by their very local settings with respect to the dominant lower-tropospheric easterly winds and the Manaus "peninsula" (see Fig. 2). For comparison purposes, an "upwind" river site (HORT) is also included in Fig. 4. The diurnal cycle at HORT is much more pronounced than at CHR5, mimicking other interior stations. The other river stations on the "downwind" side of the Manaus Peninsula (CMP1, TMB7) share this seasonal behavior with CHR5.

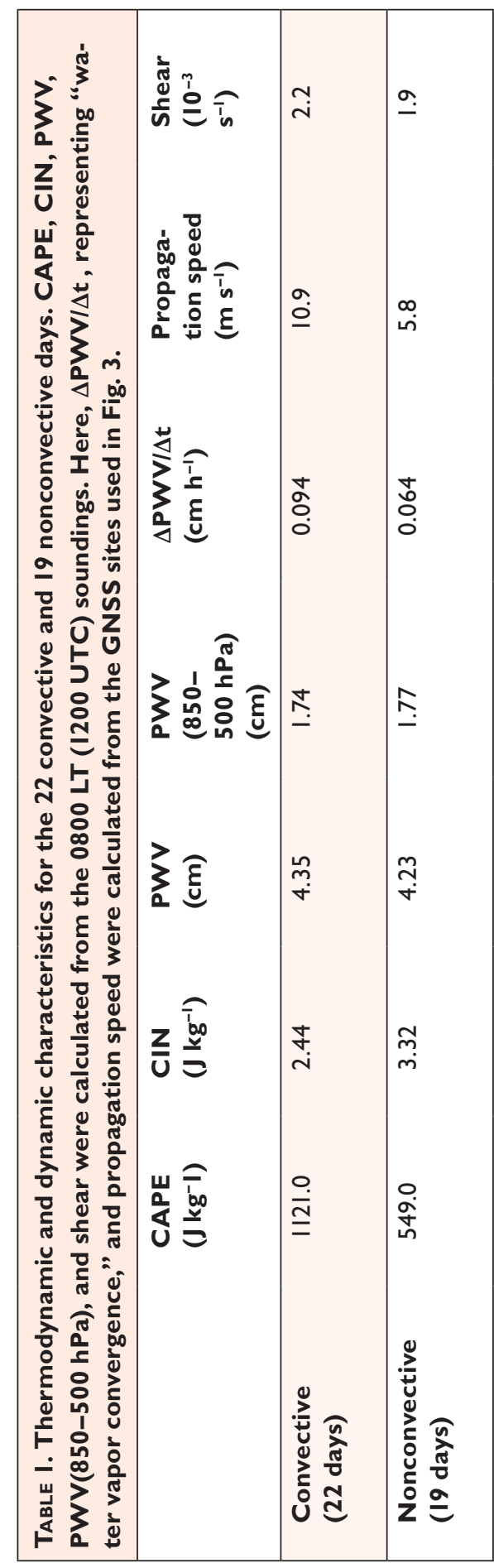

Recalling that $\Delta \mathrm{PWV} / \Delta t$ offers a glimpse of vertical motion, these results present strong evidence that local topographic effects do indeed induce mesoscale circulations. How these local convergence patterns affect the development of convection still remains to be investigated. However, these results indicate that GNSS meteorology may also be an incisive test for model-generated mesoscale circulations, even for nonconvective conditions. 
ZF29 Rainforest Site

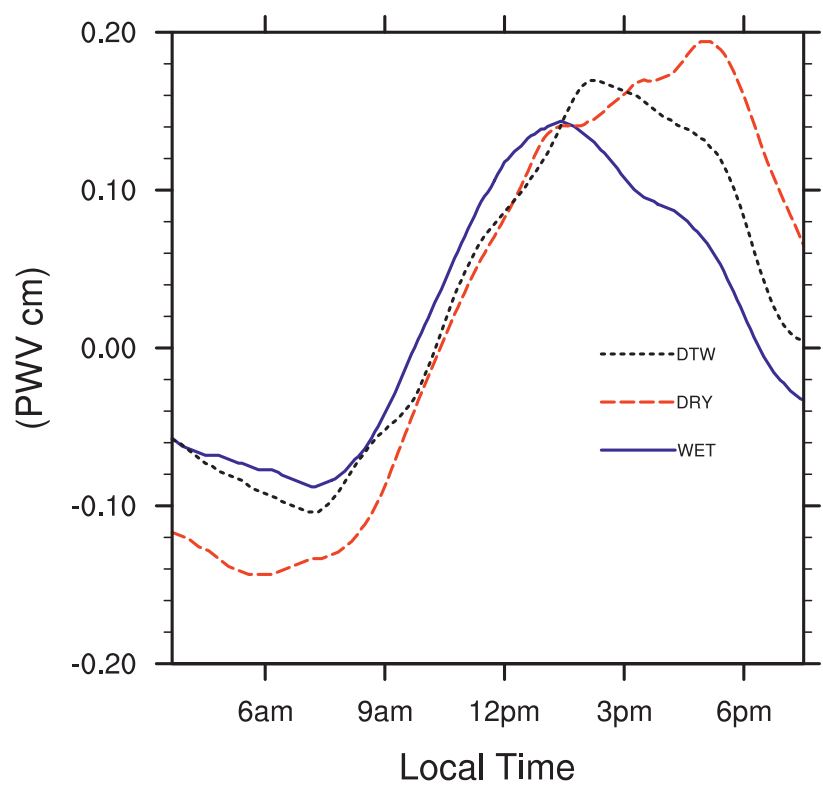

CHR5 Downwind River Site

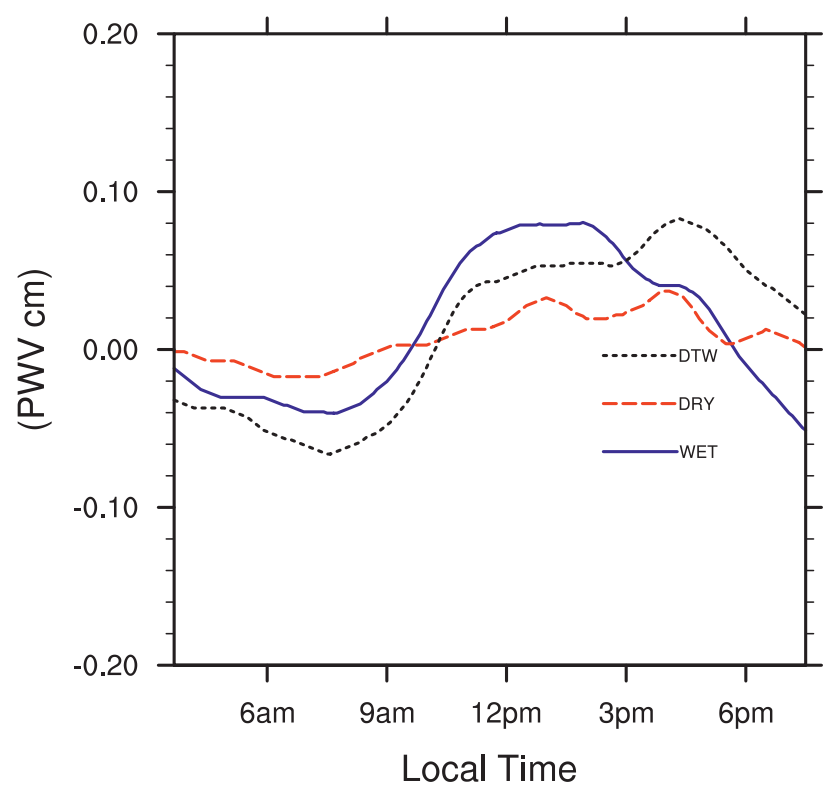

JPL6 Interior Site
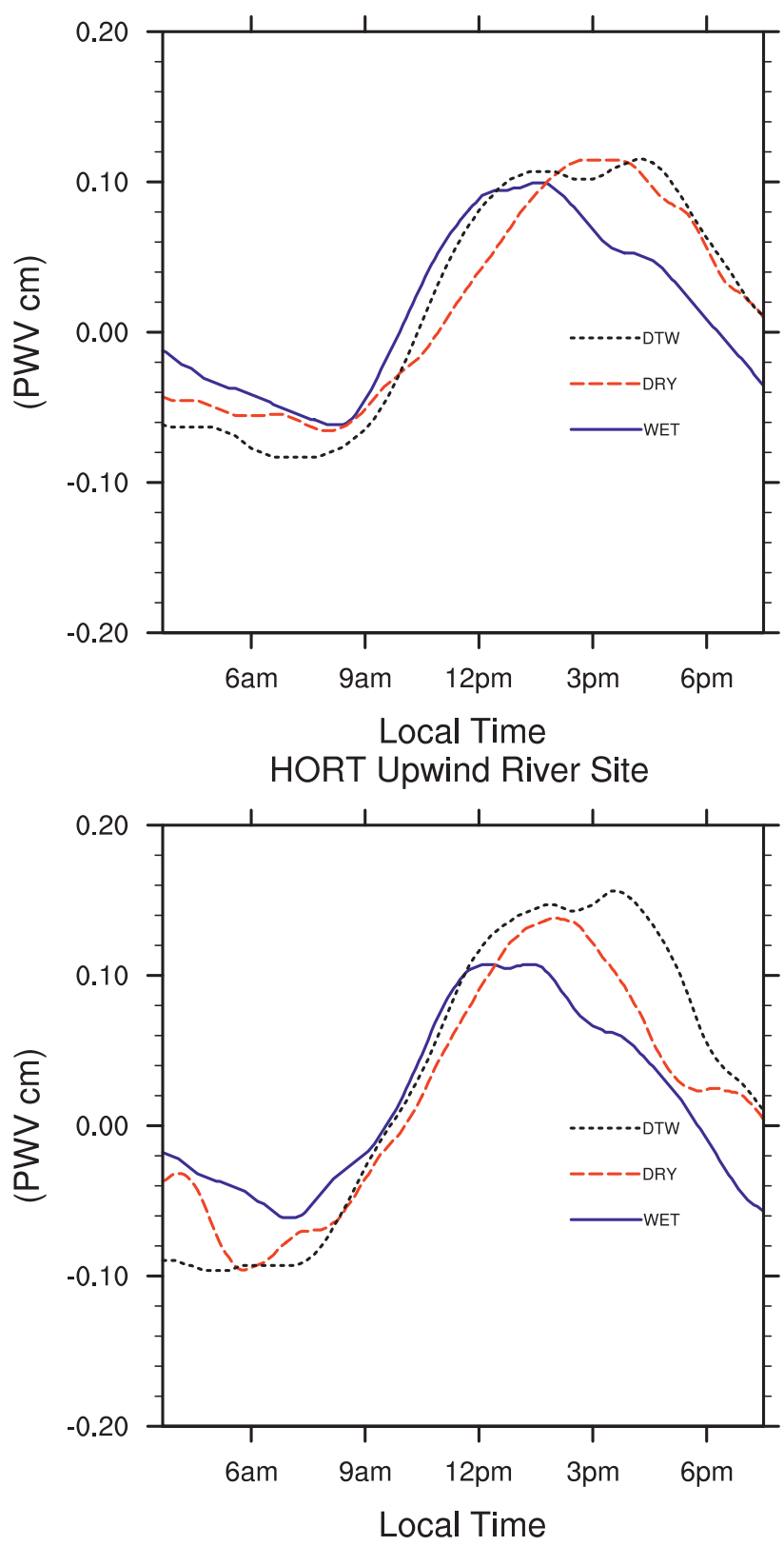

Fig. 4. Plot of the diurnal cycle of PWV deviations as a function of both season and location for Manaus stations: ZF29, JPL6, CHR5, and HORT, which represent a forest, an interior, and a pair of river sites, respectively (see Fig. 2). The blue solid lines represent the wet season, black short-dashed lines represent the dry-to-wet transition, and red long-dashed lines represent the dry season.

Future work: Manaus. The Manaus network lends itself to the study of cumulus congestus cold pools and their role in the shallow-to-deep transition to deep precipitating cumulonimbus cells and their organization on the mesoscale. Numerical modeling work by Khairoutdinov and Randall (2006), based on Amazonian-inspired boundary conditions, identifies the space and time scales that are associated with congestus cold pool formation, convergence, and the shallow-to-deep transition. The density of stations in the central portion of the network is more than adequate to capture cold pool formation. Cold pools and convective downdrafts can be identified via surface stations, while PWV fields will indicate water vapor convergence-advection. Meanwhile, GOES-12 visible and IR data document the growth, organization, and propagation of cumulus into cumulonimbus lines/ clusters. The frequent convective events over the 
Manaus network should furnish sufficient cases to ascertain the role of cold pools in the shallow-to-deep convective transition.

One exciting prospect is that with a dense network of GNSS receivers, retrieving 3D water vapor structure may be possible (Braun et al. 2001; Bastin et al. 2007; Champollion et al. 2009). Tropospheric tomography divides the Earth's atmosphere into smallvolume elements or "voxels" and uses the slant delays (between the satellite and the receiver) to estimate the refractivity in each voxel, which produces a vertical profile of refractivity. This refractivity can be transformed through algebraic iterative techniques into 3D water vapor estimates (Bender et al. 2011). This tomographic software is currently being developed at the Departamento de Informática, Universidade da Beira Interior, Covilhã, Portugal. ADGMN networks, both at Belem and Manaus, are ideal for developing such $3 \mathrm{D}$ estimates given the available soundings for constraining and validating the technique.

GNSS NETWORKS IN THE TROPICS. Though mesoscale meteorological GNSS networks are absent in the tropics, larger-scale networks have been (Bock et al. 2008) and are presently being constructed. The Continuously Operating Caribbean GPS Observational Network (COCOnet; Braun et al. 2012) is constructing 139 GNSS meteorology sites to help study Caribbean climate and meteorology and tectonic activity in the region. These permanent real-time PWV stations (101 of which are currently online), scattered across the Caribbean, can serve as anchor sites for the development of both long-term and campaign mesoscale dense networks to study convection and water vapor fields in the tropical trade wind regime. Another promising development in the tropics was the joint U.S.-Mexico North American Monsoon GNSS Transect Experiment 2013, a mesoscale meteorological transect across the complex terrain of the Sierra Madre Occidental in northwestern Mexico (Adams et al. 2014). Across the rest of Mexico, the Trans-Boundary, Land and Atmosphere Long-Term Observational and Collaborative Network (TLALOCNet; www.unavco.org/projects/major-projects /tlalocnet/tlalocnet.html) aims to develop a large-scale geodetic and atmospheric infrastructure for geoscience studies. Eighteen new real-time GNSS meteorology sites, including a permanent extension of the North American Monsoon GNSS Transect Experiment 2013, are being installed. Dense networks anchored to these Mexican and Caribbean sites would offer a wide variety of topographic settings and meteorological regimes to complement sea-breeze and continental tropical data from Brazil described above.
Since even unstable oceanic platforms can be employed, the expansion of GNSS meteorology into viable tropical oceanic regions should be promoted over ocean; local surface evaporation is a small contributor to PWV and well-measured, strengthening the interpretation of $d \mathrm{PWV} / d t$ as representative of vertical motion (Yasunaga et al. 2008). Finally, for the long term, the precision of GNSS-derived PWV will increase as more satellites come online in addition to GPS [e.g., the Global Navigation Satellite System (GLONASS), Galileo, and the BeiDou Navigation Satellite System (BDS)], increasing the value of this stable platform for observing global climate variability.

ACKNOWLEDGMENTS. We thank Dr. Antônio Manzi, Hilândia Cunha, and Cícero Leite of the INPA/ LBA for financial, logistical, and technical support for this project. Special thanks also go to Lúcia Soares de Oliveira, Edson Ferreira de Assunção, Carlos Vicente Ferreira, Francisco Paulo Santos, Prefeito of Manaquiri, Fundação Amazonas Sustentável Tumbira, Embrapa, and Reserva Ducke for hosting stations. We also thank Earle Williams and David Fitzjarrald for their comments on the original manuscript. Likewise, Brian Mapes greatly helped with the manuscript and the IDV animations. Figures were made with NCL. Support for this project and the Amazonian Dense GNSS Meteorological Network comes through Cooperation Project 0050.0045370.08.4 between PETROBRAS and INPE (Brazil) (Icaro Vitorello, principal investigator) and SMOG (PTDC/CTEATM/119922/2010) funded by FCT (Portugal). The CHUVA project was funded by FAPESP Grant 2009/15235-8. We also thank UNAVCO's Equipment Loan Program for providing GPS receivers for the Belem network. The ADGMN was carried out while the first author was on the faculty in the Programa de Pós Graduação em Clima e Ambiente, Universidade do Estado do Amazonas, Manaus, Amazonas, Brazil. Data are available upon request from corresponding author.

\section{REFERENCES}

Adams, D. K., R. M. S. Fernandes, and J. M. F. Maia, 2011a: GNSS precipitable water vapor from an Amazonian rain forest flux tower. J. Atmos. Oceanic Technol., 28, 1192-1198, doi:10.1175/JTECH-D-11-00082.1.

— - and Coauthors, 2011b: A dense GNSS meteorological network for observing deep convection in the Amazon. Atmos. Sci. Lett., 12, 207-212, doi:10.1002 /asl.312.

— S. I. Gutman, K. L. Holub, and D. S. Pereira, 2013: GNSS observations of deep convective time scales in the Amazon. Geophys. Res. Lett., 40, 2818-2823, doi:10.1002/grl.50573. 
_- C. Minjarez, Y. Serra, A. Quintanar, L. Alatorre, A. Granados, E. Vázquez, and J. Braun, 2014: Mexican GPS tracks convection from North American monsoon. Eos, Trans. Amer. Geophys. Union, 95, 61-68, doi:10.1002/2014EO070001.

Alcântara, C. R., M. A. F. Silva-Dias, E. P. Souza, and J. C. P. Cohen, 2011: Verification of the role of the low level jets in Amazon squall lines. Atmos. Res., 100, 36-44, doi:10.1016/j.atmosres.2010.12.023.

Angelis, C. F., G. R. McGregor, and C. Kidd, 2004: Diurnal cycle of rainfall over the Brazilian Amazon. Climate Res., 26, 139-149, doi:10.3354/cr026139.

Bastin, S., C. Champollion, O. Bock, P. Drobinski, and F. Masson, 2007: Diurnal cycle of water vapor as documented by a dense GPS network in a coastal area during ESCOMPTE IOP2. J. Appl. Meteor. Climatol., 46, 167-182, doi:10.1175/JAM2450.1.

Bechtold, P., J. Chaboureau, A. Beljaars, A. Betts, M. Kohler, M. Miller, and J. Redelsperger, 2004: The simulation of the diurnal cycle of convective precipitation over land in a global model. Quart. J. Roy. Meteor. Soc., 130, 3119-3137, doi:10.1256/qj.03.103.

Bender, M., G. Dick, M. Ge, Z. Deng, J. Wickert, H.-G. Kahle, A. Raabe, and G. Tetzlaff, 2011: Development of a GNSS water vapor tomography system using algebraic reconstruction technique. Adv. Space Res., 47, 1704-1720, doi:10.1016/j.asr.2010.05.034.

Betts, A. K., and C. Jakob, 2002a: Evaluation of the diurnal cycle of precipitation, surface thermodynamics, and surface fluxes in the ECMWF model using LBA data. J. Geophys. Res., 107, doi:10.1029/2001JD000427.

—, and — 2002b: Study of diurnal convective precipitation over Amazonia using a single column model. J. Geophys. Res., 107, 4732, doi:10.1029/2002JD002264.

—, G. Fisch, C. von Randow, M. A. F. Silva-Dias, J. C. P. Cohen, R. da Silva, and D. R. Fitzjarrald, 2009: The Amazonian boundary layer and mesoscale circulations. Amazonia and Global Change, Geophys. Monogr., Vol. 186, Amer. Geophys. Union, 163-181.

Bevis, M., S. Businger, T. A. Herring, C. Rocken, R. Anthes, and R. H. Ware, 1992: GPS meteorology: Sensing of atmospheric water vapor using the Global Positioning System. J. Geophys. Res., 97, 15787-15 801, doi:10.1029/92JD01517.

Bock, O., and Coauthors, 2008: West African monsoon observed with ground-based GPS receivers during African Monsoon Multidisciplinary Analysis (AMMA). J. Geophys. Res., 113, D21105, doi:10.1029/2008JD010327.

Braun, J., C. Rocken, and R. Ware, 2001: Validation of line-of-site water vapor measurements with GPS. Radio Sci., 36, 459-472, doi:10.1029/2000RS002353.
—, G. Mattioli, D. C. E. Calais, M. Jackson, R. Kursinski, M. Miller, and R. Pandya, 2012: Multi-disciplinary natural hazards research initiative begins across Caribbean basin. Eos, Trans. Amer. Geophys. Union, 93, doi:10.1029/2012EO090001.

Brenot, H., and Coauthors, 2013: Preliminary signs of the initiation of deep convection by GNSS. Atmos. Chem. Phys., 13, 5425-5449, doi:10.5194/acp-13-5425-2013.

Bretherton, C. S., M. E. Peters, and L. E. Back, 2004: Relationships between water vapor path and precipitation over the tropical oceans. J. Climate, 17, 1517-1528, doi:10.1175/1520-0442(2004)017<1517:RB WVPA>2.0.CO;2.

Calheiros, A., and L. Machado, 2014: Cloud and rain liquid water statistics in the CHUVA campaign. Atmos. Res., 144, 126-140, doi:10.1016/j .atmosres.2014.03.006.

Carbone, R. E., J. W. Wilson, T. D. Keenan, and J. M. Hacker, 2000: Tropical island convection in the absence of significant topography. Part I: Life cycle of diurnally forced convection. Mon. Wea. Rev., 128, 3459-3480, doi:10.1175/1520-0493(2000)128<3459:TI CITA $>2.0 . \mathrm{CO} ; 2$.

Champollion, C., F. Masson, M.-N. Bouin, A. Walpersdorf, E. Doerflinger, O. Bock, and J. van Baelen, 2005: GPS water vapor tomography: Preliminary results from the ESCOMPTE field experiment. Atmos. Res., 74, 253-274, doi:10.1016/j.atmosres.2004.04.003.

—, C. Flamant, O. Bock, F. Masson, D. D. Turner, and T. Weckwerth, 2009: Mesoscale GPS tomography applied to the 12 June 2002 convective initiation event of IHOP_2002. Quart. J. Roy. Meteor. Soc., 135, 645-662, doi:10.1002/qj.386.

Cohen, J. P., M. A. F. Silva-Dias, and C. A. Nobre, 1995: Environmental conditions associated with Amazonian squall lines: A case study. Mon. Wea. Rev., 123, 3163-3174, doi:10.1175/1520-0493(1995)123<3163:EC AWAS $>2.0 . \mathrm{CO} ; 2$.

Del Genio, A. D, 2012: Representing the sensitivity of convective cloud systems to tropospheric humidity in general circulation models. Surv. Geophys., 33, 637-656, doi:10.1007/s10712-011-9148-9.

Derbyshire, S. H., I. Beau, P. Bechtold, J.-Y. Grandpeix, J. Piriou, J.-L. Redelsperger, and P. M. M. Soares, 2004: Sensitivity of moist convection to environmental humidity. Quart. J. Roy. Meteor. Soc., 130, 3055-3079, doi:10.1256/qj.03.130.

Duan, J., and Coauthors, 1996: GPS meteorology: Direct estimation of the absolute value of precipitable water. J. Appl. Meteor., 35, 830-838, doi:10.1175/15200450(1996)035<0830:GMDEOT>2.0.CO;2.

Fitzjarrald, D. R., R. K. Sakai, O. L. L. Moraes, R. C. de Oliveira, O. C. Acevedo, M. J. Czikowsky, and 
T. Beldini, 2008: Spatial and temporal rainfall variability near the Amazon-Tapajós confluence. J. Geophys. Res., 113, G00B11, doi:10.1029/2007JG000596.

Fovell, R. G., 2005: Convective initiation ahead of the sea-breeze front. Mon. Wea. Rev., 133, 264-278, doi:10.1175/MWR-2852.1.

Garstang, M., and Coauthors, 1990: The Amazon Boundary-Layer Experiment (ABLE 2B): A meteorological perspective. Bull. Amer. Meteor. Soc., 71, 19-32, doi:10.1175/1520-0477(1990)071<0019:TAB LEA $>2.0 . C O ; 2$.

—, H. L. Massie Jr., J. Halverson, S. Greco, and J. Scala, 1994: Amazon coastal squall lines. Part I: Structure and kinematics. Mon. Wea. Rev., 122, 608-622, doi:10.1175/1520-0493(1994)122<0608:ACSLPI >2 .0.CO;2.

Grabowski, W. W., and M. W. Moncrieff, 2004: Moisture-convection feedback in the tropics. Quart. J. Roy. Meteor. Soc., 130, 3081-3104, doi:10.1256 /qj.03.135.

—-, and Coauthors, 2006: Daytime convective development over land: A model intercomparison based on LBA observations. Quart. J. Roy. Meteor. Soc., 132, 317-344, doi:10.1256/qj.04.147.

Greco, S., and Coauthors, 1990: Rainfall and surface kinematic conditions over central Amazonia during ABLE 2B. J. Geophys. Res., 95, 17 001-17 014, doi:10.1029/JD095iD10p17001.

Hohenegger, C., and B. Stevens, 2013: Preconditioning deep convection with cumulus convection. J. Atmos. Sci., 70, 448-464, doi:10.1175/JAS-D-12-089.1.

Holloway, C. E., and J. D. Neelin, 2009: Moisture vertical structure, column water vapor, and tropical deep convection. J. Atmos. Sci., 66, 1665-1683, doi:10.1175/2008JAS2806.1.

Kealy, J., J. Foster, and S. Businger, 2012: GPS meteorology: An investigation of ocean-based precipitable water estimates. J. Geophys. Res., 117, D17303, doi:10.1029/2011JD017422.

Khairoutdinov, M., and D. Randall, 2006: High-resolution simulation of shallow-to-deep convection transition over land. J. Atmos. Sci., 63, 3421-3436, doi:10.1175/JAS3810.1.

Kousky, V., 1980: Diurnal rainfall variation in Northeast Brazil. Mon. Wea. Rev., 108, 488-498, doi:10.1175/1520 -0493(1980)108<0488:DRVINB>2.0.CO;2.

Kuang, Z., and C. S. Bretherton, 2006: A mass-flux scheme view of a high-resolution simulation of a transition from shallow to deep cumulus convection. J. Atmos. Sci., 63, 1895-1909, doi:10.1175/JAS3723.1.

Kursinski, E. R., G. A. Hajj, S. Leroy, and B. Herman, 2000: The GPS radio occultation technique. Terr. Atmos. Ocean. Sci., 11, 53-114.
- - and Coauthors, 2008: Water vapor and surface observations in northwestern Mexico during the 2004 NAME enhanced observing period. Geophys. Res. Lett., 35, L03815, doi:10.1029/2007GL031404.

Lintner, B. R., C. E. Holloway, and J. D. Neelin, 2011: Column water vapor statistics and their relationship to deep convection, vertical and horizontal circulation, and moisture structure at Nauru. J. Climate, 24, 5454-5466, doi:10.1175/JCLI-D-10-05015.1.

Machado, L. A. T., H. Laurent, N. Dessay, and I. Miranda, 2004: Seasonal and diurnal variability of convection over the Amazonia: A comparison of different vegetation types and large scale forcing. Theor. Appl. Climatol., 78, 61-77, doi:10.1007/s00704-004-0044-9.

— , and Coauthors, 2014: The CHUVA Project: How does convection vary across Brazil? Bull. Amer. Meteor. Soc., 95, 1365-1380, doi:10.1175/BAMS -D-13-00084.1.

Mapes, B., and R. Neale, 2011: Parameterizing convective organization to escape the entrainment dilemma. J. Adv. Model. Earth Syst., 3, M06004, doi:10.1029/2011MS000042.

—, T. Warner, and M. Xu, 2003: Diurnal patterns of rainfall in northwestern South America. Part III: Diurnal gravity waves and nocturnal convection offshore. Mon. Wea. Rev., 131, 830-844, doi:10.1175/1520-0493(2003)131<0830:DPORIN $>2$ .0.CO;2.

_-, R. Milliff, and J. Morzel, 2009: Composite life cycle of maritime tropical mesoscale convective systems in scatterometer and microwave satellite observations. J. Atmos. Sci., 66, 199-208, doi:10.1175/2008JAS2746.1.

Masunaga, H., 2013: A satellite study of tropical moist convection and environmental variability. J. Atmos. Sci., 70, 2443-2466, doi:10.1175/JAS-D-12-0273.1.

Mazany, R. A., S. Businger, S. I. Gutman, and W. Roeder, 2002: A lightning prediction index that utilizes GPS integrated precipitable water vapor. Wea. Forecasting, 17, 1034-1047, doi:10.1175/1520 -0434(2002)017<1034:ALPITU>2.0.CO;2.

Moncrieff, M. W., and C. Liu, 1999: Convective initiation by density currents: Role of convergence, shear, and dynamical organization. Mon. Wea. Rev., 127, 2455-2464, doi:10.1175/1520-0493(1999)127<2455:CI $\mathrm{BDCR}>2.0 . \mathrm{CO} ; 2$.

—, D. E. Waliser, M. J. Miller, M. A. Shapiro, G. R. Asrar, and J. Caughey, 2012: Multiscale convective organization and the YOTC Virtual Global Field Campaign. Bull. Amer. Meteor. Soc., 93, 1171-1187, doi:10.1175/BAMS-D-11-00233.1.

Neelin, J. D., O. Peters, and K. Hales, 2009: The transition to strong convection. J. Atmos. Sci., 66, 2367-2384, doi:10.1175/2009JAS2962.1. 
Park, S., 2014: A unified convection scheme (UNICON). Part I: Formulation. J. Atmos. Sci., 71, 3902-3930, doi:10.1175/JAS-D-13-0233.1.

Peters, O., J. D. Neelin, and S. W. Nesbitt, 2009: Mesoscale convective systems and critical clusters. J. Atmos. Sci., 66, 2913-2924, doi:10.1175/2008JAS2761.1.

Raymond, D. J., 2000: Thermodynamic control of tropical rainfall. Quart. J. Roy. Meteor. Soc., 126, 889-898, doi:10.1002/qj.49712656406.

Rio, C., F. Hourdin, J.-Y. Grandpeix, and J.-P. Lafore, 2009: Shifting the diurnal cycle of parameterized deep convection over land. Geophys. Res. Lett., 36, L07809, doi:10.1029/2008GL036779.

Robinson, F. J., M. D. Patterson, and S. C. Sherwood, 2013: A numerical modeling study of the propagation of idealized sea-breeze density currents. J. Atmos. Sci., 70, 653-668, doi:10.1175/JAS-D-12-0113.1.

Rocken, C., R. H. Ware, T. V. Hove, F. Solheim, C. Alber, J. Johnson, M. Bevis, and S. Businger, 1993: Sensing atmospheric water vapor with the Global Positioning System. Geophys. Res. Lett., 20, 2631-2634, doi:10.1029/93GL02935.

—, J. Johnson, T. V. Hove, and T. Iwabuchi, 2005: Atmospheric water vapor and geoid measurements in the open ocean with GPS. Geophys. Res. Lett., 32, L12813, doi:10.1029/2005GL022573.

Romps, D. M., and Z. M. Kuang, 2010: Do undiluted convective plumes exist in the upper tropical troposphere? J. Atmos. Sci., 67, 468-484, doi:10.1175/2009JAS3184.1.

Rougier, J., D. M. H. Sexton, J. M. Murphy, and D. Stainforth, 2009: Analyzing the climate sensitivity of the HadSM3 climate model using ensembles from different but related experiments. J. Climate, 22, 3540-3557, doi:10.1175/2008JCLI2533.1.

Saad, S. I., H. R. da Rocha, M. A. F. Silva-Dias, and R. Rosolem, 2010: Can the deforestation breeze change the rainfall in Amazonia? A case study for the BR-163 highway region. Earth Interact., 14, doi:10.1175/2010EI351.1.

Sapucci, L. F., L. A. T. Machado, J. F. G. Monico, and A. Plana-Fattori, 2007: Intercomparison of integrated water vapor estimates from multisensors in the Amazonian region. J. Atmos. Oceanic Technol., 24, 1880-1894, doi:10.1175/JTECH2090.1.

Schlemmer, L., and C. Hohenegger, 2014: The formation of wider and deeper clouds as a result of cold-pool dynamics. J. Atmos. Sci., 71, 2842-2858, doi:10.1175 /JAS-D-13-0170.1.

Seko, H., H. Nakamura, Y. Shoji, and T. Iwabuchi, 2004: The meso- $\gamma$ scale water vapor distribution associated with a thunderstorm calculated from a dense network of GPS receivers. J. Meteor. Soc. Japan, 82, 569-586, doi:10.2151/jmsj.2004.569.
Sherwood, S., and R. Warhlich, 1999: Observed evolution of tropical deep convective events and their environment. Mon. Wea. Rev., 127, 1777-1795, doi:10.1175/1520 -0493(1999)127<1777:OEOTDC>2.0.CO;2.

- , R. Roca, T. Weckwerth, and N. Andronova, 2009: Tropospheric water vapor, convection and climate: A critical review. Rev. Geophys., 48, RG2001, doi:10.1029/2009RG000301.

—, D. Hernandez-Decker, and M. Colin, 2013: Slippery thermals and the cumulus entrainment paradox. J. Atmos. Sci., 70, 2426-2442, doi:10.1175 /JAS-D-12-0220.1.

Silva-Dias, M. A. F., and Coauthors, 2002: Cloud and rain processes in a biosphere atmosphere interaction context in the Amazon region. J. Geophys. Res., 107, 8072, doi:10.1029/2001JD000335.

_ , P. L. Silva-Dias, M. Longo, D. R. Fitzjarrald, and A. S. Denning, 2004: River breeze circulation in eastern Amazonia: Observations and modelling results. Theor. Appl. Climatol., 78, 111-121, doi:10.1007 /s00704-004-0047-6.

Solheim, F. S., J. Vivekanandan, R. H. Ware and C. Rocken, 1999: Propagation delays induced in GPS signals by dry air, water vapor, hydrometeors, and other particulates. J. Geophys. Res., 104, 9663-9670, doi:10.1029/1999JD900095.

Tompkins, A., 2001a: Organization of tropical convection in low vertical wind shears: The role of cold pools. J. Atmos. Sci., 58, 1650-1672, doi:10.1175/1520 -0469(2001)058<1650:OOTCIL >2.0.CO;2.

- 2001b: Organization of tropical convection in low vertical wind shears: The role of water vapor. J. Atmos. Sci., 58, 529-545, doi:10.1175/1520 $-0469(2001) 058<0529:$ OOTCIL $>2.0$. CO;2.

Ulanski, S., and M. Garstang, 1978: The role of surface divergence and vorticity in the life cycle of convective rainfall. Part I: Observation and analysis. J. Atmos. Sci., 35, 1047-1062, doi:10.1175/1520 -0469(1978)035<1047:TROSDA >2.0.CO;2.

Waite, M. L., and B. Khouider, 2010: The deepening of tropical convection by congestus preconditioning. J. Atmos. Sci., 67, 2601-2615, doi:10.1175/2010JAS3357.1.

Wang, J., and Coauthors, 2009: Impact of deforestation in the Amazon basin on cloud climatology. Proc. Natl. Acad. Sci. USA, 106, 3670-3674, doi:10.1073 /pnas.0810156106.

Wolfe, D. E., and S. I. Gutman, 2000: Developing an operational, surface-based, GPS, water vapor observing system for NOAA: Network design and results. J. Atmos. Oceanic Technol., 17, 426-440, doi:10.1175/1520 -0426(2000)017<0426:DAOSBG >2.0.CO;2.

Wu, C.-M., B. Stevens, and A. Arakawa, 2009: What controls the transition from shallow to 
deep convection? J. Atmos. Sci., 66, 1793-1806, doi:10.1175/2008JAS2945.1.

Yasunaga, K., M. Fujita, T. Ushiyama, K. Yoneyama, Y. N. Takayabu, and M. Yoshizaki, 2008: Diurnal variations in precipitable water observed by shipborne GPS over the tropical Indian Ocean. SOLA, 4, 97-100, doi:10.2151/sola.2008-025.

Yeo, K., and D. M. Romps, 2013: Measurement of convective entrainment using Lagrangian particles. J. Atmos. Sci., 70, 266-277, doi:10.1175/JAS-D-12-0144.1.
Zeng, X., 1999: The relationship among precipitation, cloud-top temperature, and precipitable water over the tropics. J. Climate, 12, 2503-2514, doi:10.1175/1520-0442(1999)012<2503:TRAPCT $>2.0 . \mathrm{CO} ; 2$.

Zhang, C., J. Gottschalck, E. D. Maloney, M. Moncrieff, F. Vitart, D. E. Waliser, B. Wang, and M. C. Wheeler, 2013: Cracking the MJO nut. Geophys. Res. Lett., 40, 1223-1230, doi:10.1002/grl.50244.

\section{NEW FROM AMS BOOKS!}

\section{"An engrossing account of New England's worst natural catastrophe."}

- KeRRY emANUEL, Professor of Atmospheric Science, MIT

\section{Taken by Storm, 1938:}

A Social and Meteorological History of the Great New England Hurricane LOURDES B. AVILÉS

When the Great New England Hurricane of 1938 hit the Northeast unannounced, it changed everything from the landscape, to Red Cross and Weather Bureau protocols, to the measure of Great Depression relief New Englanders would receive, and the resulting pace of regional economic recovery. The science behind this storm is presented here for the first time, with new data that sheds light on the motivations of the Weather Bureau forecasters. This compelling history successfully weaves science, historical accounts, and social analyses to create a comprehensive picture of the most powerful and devastating hurricane to hit New England to date.

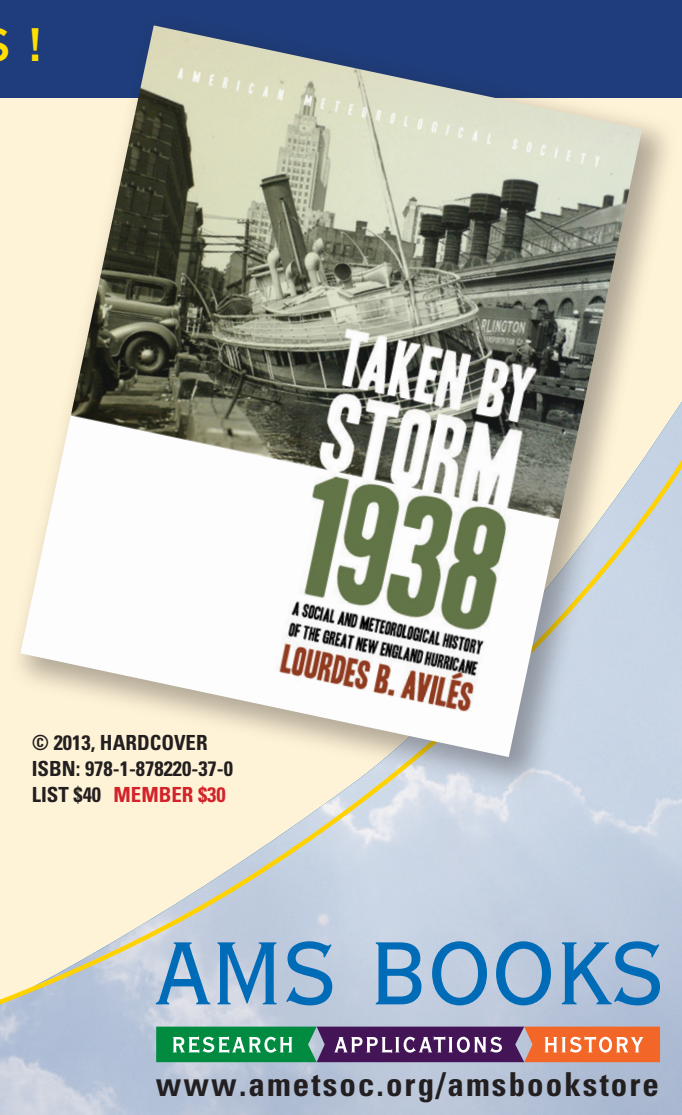




\section{EYEWITNESS \\ Evolution of the AtMospheric Sciences}

\section{by ROBERT G. FLEAGLE}

Eyewitness: Evolution of the Atmospheric Sciences describes how the atmospheric sciences were transformed in the span of the author's professional career from its origins in primitive weather forecasting to its current focus on

numerical modeling of environmental change. It describes the author's observations of persons, events, and institutions beginning with graduate study during the Second World War and

moving on to continuing expansion of the atmospheric sciences and technologies, through development of a major university department, development of new scientific and professional institutions, and to the role that the science of the atmosphere now plays in climate change and other issues of social and political policy.

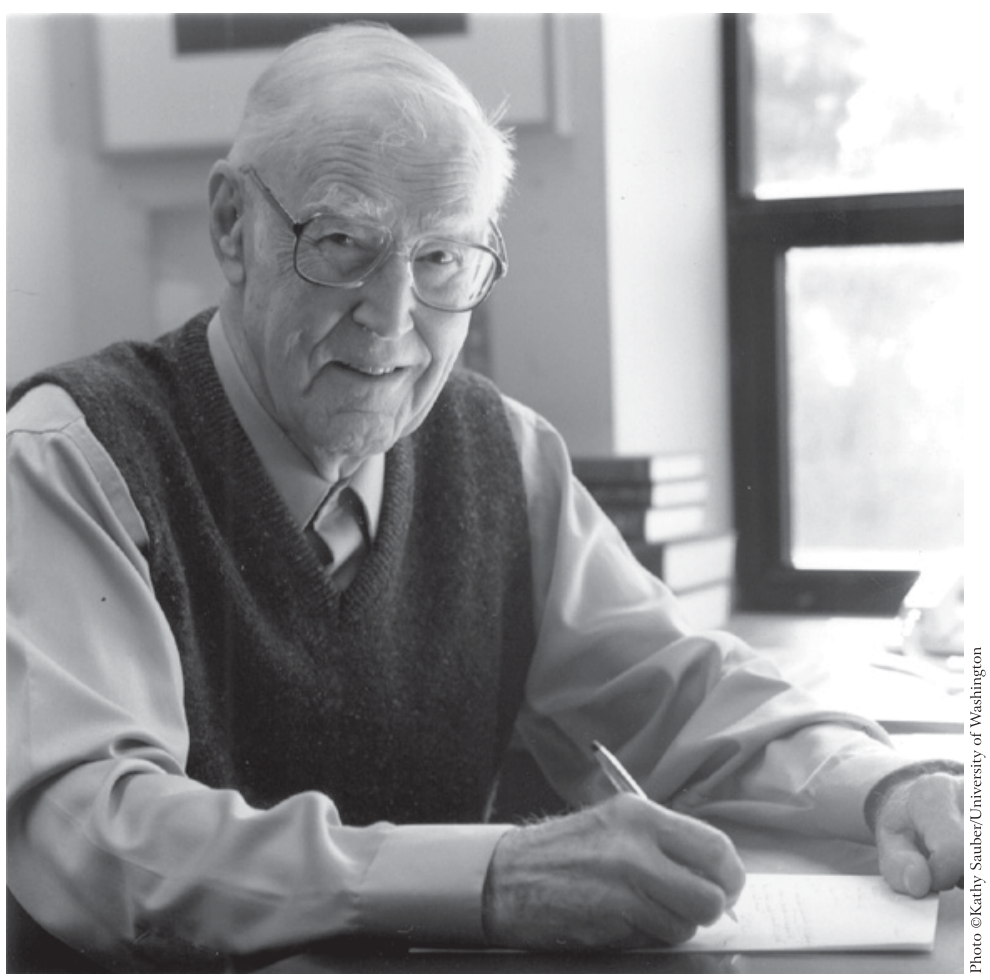

EYEWITNESS: EVOLUTION OF THE ATMOSPHERIC SCIENCES

ISBN 1-878220-39-X, 129 pp., hardbound, \$75 list/\$55 member.

Order online: www.ametsoc.org/amsbookstore

or see the order form at the back of this issue.

\section{ABOUT THE AUTHOR}

Robert G. Fleagle earned degrees in physics and meteorology at The Johns Hopkins University and New York University and began his professional career in 1948 at the University of Washington (UW). His research has focused on the structure of midlatitude cyclones, the physics and structure of the surface boundary layer, and processes of air-sea interaction. He is the author of about 100 papers published in scientific journals and of books on atmospheric physics and global environmental change. Applications of science to social and political policy have been important motivations for his career and have occupied his attention increasingly as the decades passed.

Fleagle participated at close range in the beginnings and growth of a major university department and of the University Corporation for Atmospheric Research (UCAR). In 1963 and 1964 he served as a staff specialist in the Office of Science and Technology, Executive Office of the President, and in 1977-78 he served as consultant to the National Oceanic and Atmospheric Administration. He has held many administrative posts including chairman of the UW Department of Atmospheric Sciences (1967-77), chairman of the National Academy of Sciences Committee on Atmospheric Sciences (1969-73), 